
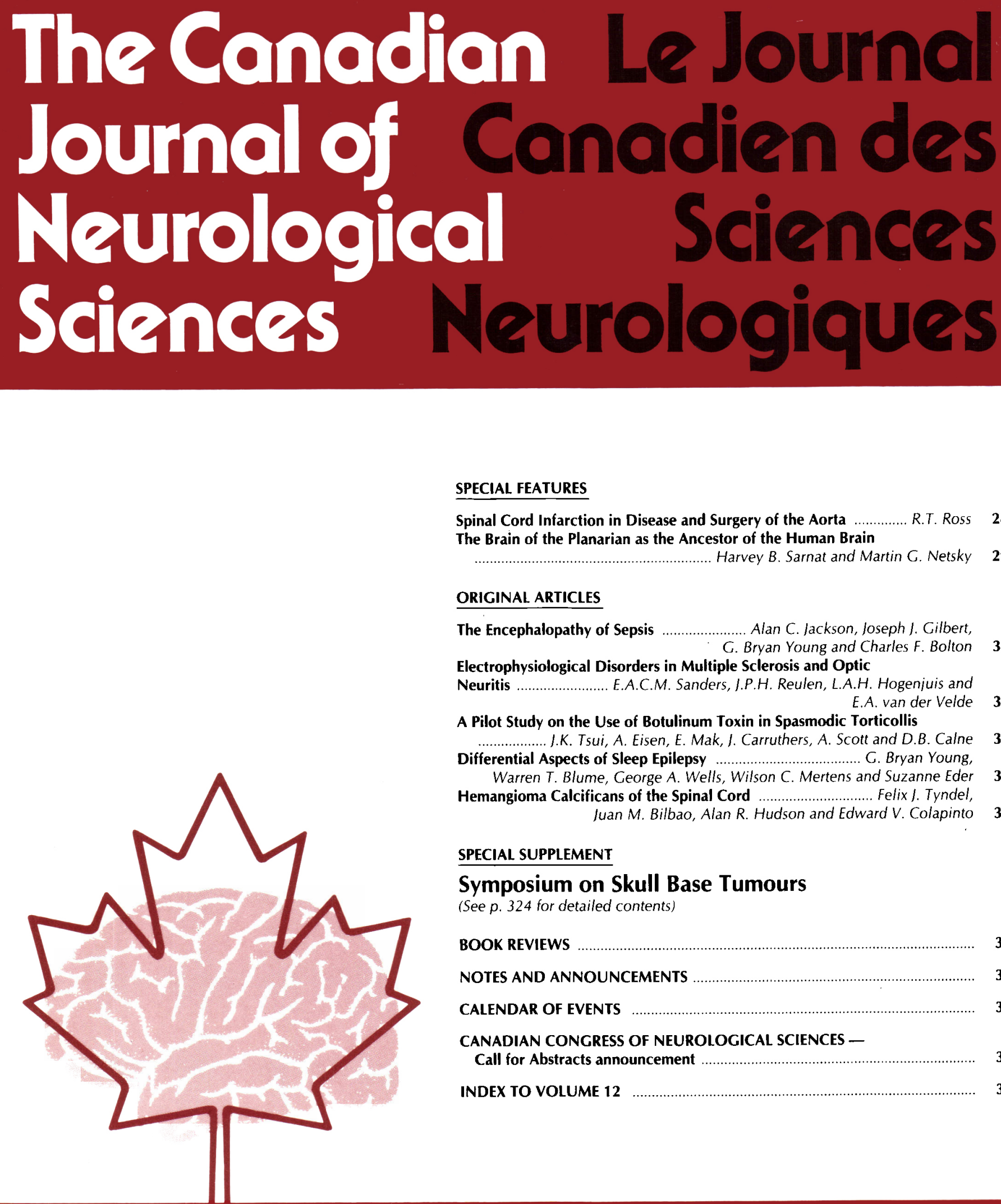

\title{
SPECIAL FEATURES
}

Spinal Cord Infarction in Disease and Surgery of the Aorta R.T. Ross The Brain of the Planarian as the Ancestor of the Human Brain Harvey B. Sarnat and Martin G. Netsky

\section{ORIGINAL. ARTICLES}

The Encephalopathy of Sepsis

Alan C. Jackson, Joseph I. Gilbert, G. Bryan Young and Charles F. Bolton

Electrophysiological Disorders in Multiple Sclerosis and Optic

Neuritis .................. E.A.C.M. Sanders, I.P.H. Reulen, L.A.H. Hogenjuis and E.A. van der Velde

A Pilot Study on the Use of Botulinum Toxin in Spasmodic Torticollis .. I.K. Tsui, A. Eisen, E. Mak, I. Carruthers, A. Scott and D. B. Calne

Differential Aspects of Sleep Epilepsy ................................... G. Bryan Young, Warren T. Blume, George A. Wells, Wilson C. Mertens and Suzanne Eder Hemangioma Calcificans of the Spinal Cord .......................... Felix J. Tyndel, Iuan M. Bilbao, Alan R. Hudson and Edward V. Colapinto

\section{SPECIAL SUPPLEMENT}

\section{Symposium on Skull Base Tumours \\ (See p. 324 for detailed contents)}

BOOK REVIEWS

NOTES AND ANNOUNCEMENTS

CALENDAR OF EVENTS

\section{CANADIAN CONGRESS OF NEUROLOGICAL SCIENCES -}

Call for Abstracts announcement

INDEX TO VOLUME 12

\section{Canadian Congress of \\ Neurological Sciences London, Ontario}

June 24 - 28, 1986

\section{The Official Journal of}

The Canadian Neurological Society

The Canadian Neurosurgical Society

The Canadian Society of Clinical Neurophysiologists

The Canadian Association for Child Neurology 


\section{SPECIAL SUPPLEMENT}

\section{Symposium on \\ Skull Base Tumours}

Presented in Conjunction With The 1985 William S. Keith

Visiting Professorship in Neurosurgery

Toronto Western Hospital and University of Toronto

February 26th - 28th, 1985

William Keith Visiting Professor: Patrick J. Derome, M.D., Paris, France

Guest Editor: Ross Fleming, M.D., M.S., F.R.C.S.(C) 


\title{
Symposium on Skull Base Tumours
}

\author{
Table of Contents
}

Introduction

Fleming, J.F.R.

Nuclear Magnetic Resonance Imaging of Skull Base Lesions

Potts, D.C. and Zimmerman, R.D.

Visual Dysfunction with Basal Skull Tumours

Sharpe, I.A.

Monitoring of Sensory Evoked Potentials During Surgery of Skull Base Tumours

Centili, F., Lougheed, W.M., Yamashiro, K. and Corrado, C.

Super-Selective Angiography and Embolization of Skull Base Tumours

Ter Brugge, K.G., Lasjaunias, P. and Chiu, M.C.

Surgical Management of Tumours Invading the Skull Base

Derome, P.J.

Craniopharyngiomas

Hoffman, H.J.

Acoustic Neuromas: Management of 204 Cases

Tator, C.H.

Pathological Diversity in Clinical Syndromes of Pituitary Hypersecretion: Its Significance

in Evaluating Their Surgical Treatment

Smyth, $H$. 358

Radiation Therapy of Tumours Involving the Skull Base

Payne, D.C.

Interstitial Irradiation of Skull Base Tumours

Bernstein, M. and Cutin, P.H.

Photo-Dynamic Therapy (PDT): Cavitary Photo-Illumination of Malignant Cerebral Tumours

Using a Laser Coupled Inflatable Balloon

Muller, P.J. and Wilson, B.C. 